\title{
Three-dimensional spatial structure: nematodes in a sandy tidal flat
}

\author{
P. J. Somerfield*, S. L. Dashfield, R. M. Warwick \\ Plymouth Marine Laboratory, Prospect Place, Plymouth PL1 3DH, UK
}

\begin{abstract}
Benthic infauna live in a three-dimensional world, and patterns of horizontal distribution may vary with depth in the sediment, as may the mechanisms that determine those patterns. This study examines how horizontal spatial structure varies with depth in a semi-exposed coarse-sand flat adjacent to St Martin's, one of the Isles of Scilly, UK. Nematode samples were collected from 3 sediment depth horizons ( 0 to 5,5 to 10 and 10 to $15 \mathrm{~cm}$ ) in a nested hierarchical design, with samples 0.1 , 1 and $10 \mathrm{~m}$ apart. Results show that spatial patterns are strongest amongst samples of intermediate depth $(5$ to $10 \mathrm{~cm})$, and generally insignificant amongst samples collected from 10 to $15 \mathrm{~cm}$. There is short-order spatial autocorrelation in surface $(0$ to $5 \mathrm{~cm}$ ) samples, with samples collected $10 \mathrm{~cm}$ apart being significantly more alike than samples collected further apart. We postulate that this is because spatial structure of nematodes in surface sediments is determined by patchiness induced by interactions between the water column and the physical structure of the surface layers of the sediment, which are constantly reworked by wind and tides. The deeper layers, 10 to $15 \mathrm{~cm}$ below the surface, are constantly reworked by a dense population of heart urchins Echinocardium cordatum. It is only in the intermediate horizon that relatively stable conditions allow nematode assemblages to establish spatial structure over a range of scales. It is concluded that the interaction between sediment permeability, and therefore interfacial advection, and bioturbation in controlling infaunal diversity and spatial patterns is potentially important.
\end{abstract}

KEY WORDS: Nematodes · Spatial structure · Vertical distribution · Echinocardium • Bioturbation · Advection

Resale or republication not permitted without written consent of the publisher

\section{INTRODUCTION}

Unlike the epifauna of hard substrata, the benthic infauna of sediments live in a three-dimensional world, and the mechanisms that determine horizontal patterns of distribution may vary with depth in the sediment. Despite this, descriptions of horizontal patterns of distribution are usually depth integrated, which masks these depth differences and, consequently, patterns may be difficult to interpret in terms of the underlying processes that determine them.

Sediment-dwelling, free-living nematodes have a range of life-history characteristics such as small body size, in situ feeding, a lack of a specific dispersal stage, and in situ reproduction followed by rapid development, which tie them closely to the sediment in which they live. One consequence is that changes in nema- tode community structure in response to environmental changes in the sediment may be very rapid. There is a general hypothesis that in areas which we view as homogenous, such as intertidal flats, the horizontal distribution of meiofauna is patchy and unpredictable (Fleeger \& Decho 1987). On the other hand, studies of the vertical distribution of meiofauna in similar habitats have shown that distribution patterns may be predictable and, in response to physical and chemical fluctuations, species-specific migrations may occur (Joint et al. 1982, Steyaert et al. 2001). A recent study (Warwick et al. 2006) suggested that spatial distributions of metazoans in a coarse-sand flat have fractal properties over certain domains and that for smaller organisms (corresponding to the meiofauna) vertical clustering is an important component of their spatial structure. 
Spatial structure may be defined, and therefore detected in statistical analyses, in a large variety of ways. Many of these rely on implicit assumptions concerning the distributions of organisms in the absence of spatial structure. For example, in a univariate context a failure to detect departure from a Poisson distribution in a statistical test (such as a $\chi^{2}$ test on variance:mean ratios) may be used to demonstrate a random distribution, reinforcing the idea that randomness in this context implies a lack of spatial structure. In fact the presence and absence of spatial structure are both possible even if organisms are distributed according to a Poisson process at some scale or other. Nevertheless, it is important to have some criteria against which to judge the presence and relative strength of a spatial structuring process. Here, we chose to consider spatial structure as being present when samples collected from locations closer together were significantly more (or less) similar to each other than samples collected from locations further apart, in terms of their assemblage composition. As such the general hypothesis concerns multivariate spatial autocorrelation rather than some measure of patchiness, a context within which many studies of spatial structure have been analysed and interpreted (Somerfield \& Gage 2000).

Studies of spatial structure of nematodes in sediments have tended to focus on either horizontal patterns, using samples collected to a standard depth (e.g. Hogue \& Miller 1981, Blome et al. 1999), or vertical structure within small areas (e.g. Platt 1977, Joint et al. 1982). We examined the extent to which horizontal

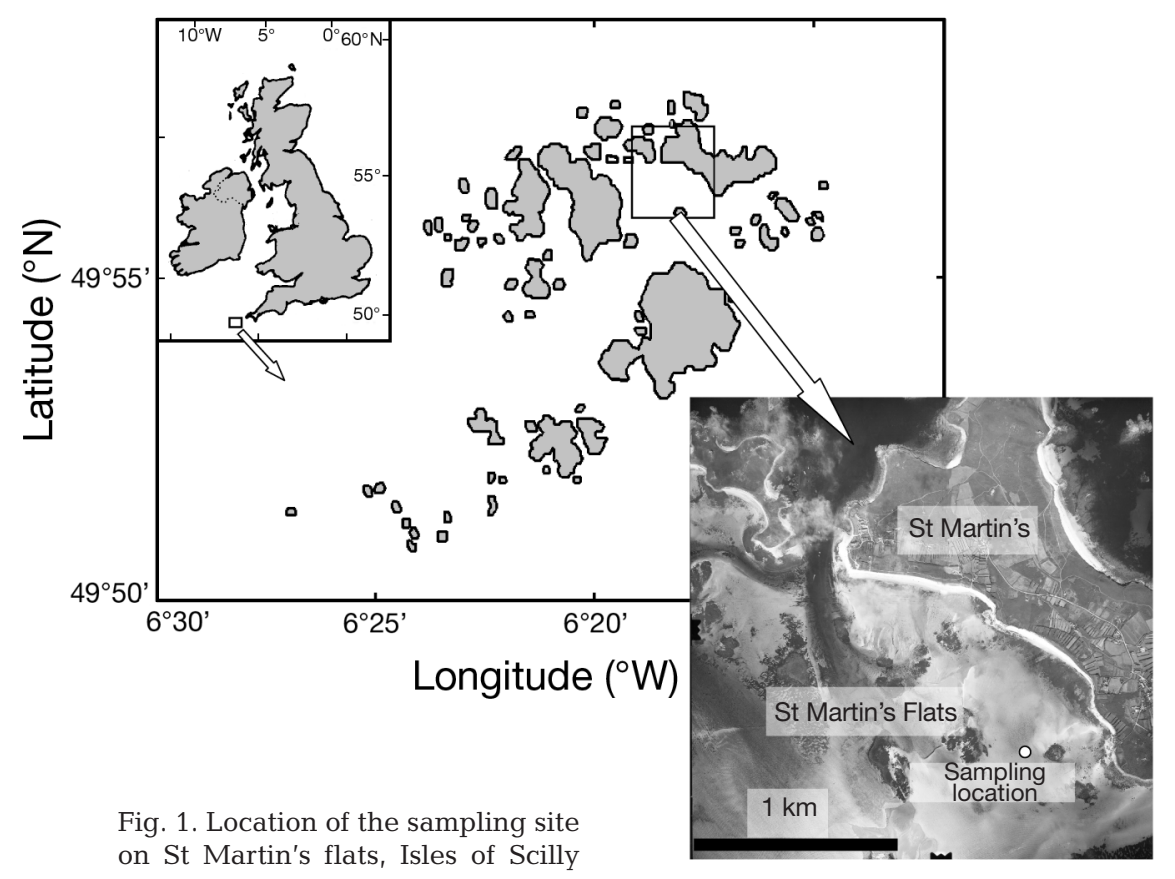

structure in a free-living nematode assemblage varied at different depths within an apparently homogeneous area of coarse intertidal sand, and interpreted perceived patterns in light of the likely processes operating at various spatial scales in different depth horizons within the sediment.

\section{MATERIALS AND METHODS}

Study site and field sampling. Samples were collected from LWST (low water spring tides) on St Martin's flats, Isles of Scilly (Fig. 1). The islands are a granite archipelago situated $40 \mathrm{~km}$ south-west of the English mainland. The large semi-exposed sandflat is located on the south of the island of St Martin's and consists of coarse sand (median diameter: $575 \mu \mathrm{m}$ ) with $<0.1 \%$ silt/clay, a permanent water table, and no visual evidence of reducing conditions (such as a blackening of the sediment) in the upper $15 \mathrm{~cm}$. Samples of sediment for the determination of free-living nematode assemblages were taken on 18 April 1999. Cores with an internal diameter of $4 \mathrm{~cm}$ were collected according to a nested hierarchical design, with samples 0.1, 1.0 and $10 \mathrm{~m}$ apart (Fig. 2). Cores were carefully inserted into the sediment, during which gentle suction was applied by mouth to reduce core compression, and sealed at the top with a rubber bung. They were then dug out and sealed from below. Each core was sliced into 3 depth horizons ( 0 to 5, 5 to 10 and 10 to $15 \mathrm{~cm}$ ) by loosening the upper seal and allowing the core to slide slowly out of the bottom of the tube into sample containers (Somerfield et al. 2005). The samples were fixed in $10 \%$ formalin. Cores that were obviously disrupted at any stage during the process were discarded.

A population of Echinocardium cordatum inhabited the sediment, and the depths and densities at which they were living in the study area were estimated in carefully dug pits. Surface openings of $E$. cordatum respiratory shafts were counted in a $10 \times 10$ grid of $1 \mathrm{~m}^{2}$ quadrats. This is likely to underestimate the densities of the animals, as this species makes single shafts (Nichols 1959), but not all are visible at the surface. However, we believe that this procedure gives an adequate indication of the population's spatial distribution.

Sample processing. Extraction and mounting of nematodes followed Somerfield \& Warwick (1996) and Somerfield et al. (2005). After decanting the 


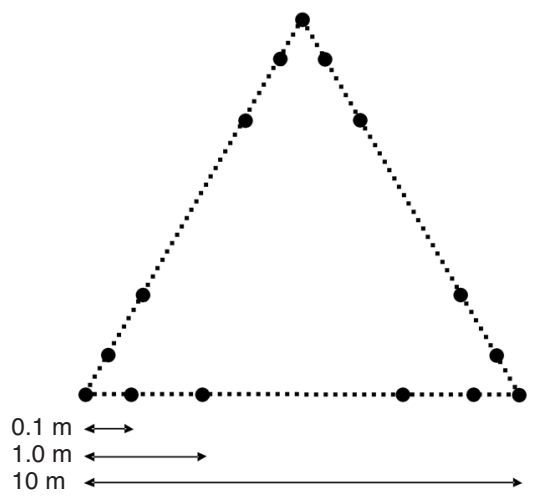

Fig. 2. Schematic of the sampling design. Cores were collected according to a hierarchical design at distances of 0.1 , 1.0 and $10 \mathrm{~m}$ apart and subsequently sectioned into $5 \mathrm{~cm}$ depth increments

samples 5 times onto a $63 \mu \mathrm{m}$ sieve, nematodes were extracted with Ludox-TM, with a specific gravity of 1.15. The extraction was repeated 4 times, and the meiofauna were stored in $4 \%$ formalin. Prior to mounting, samples were washed into a glass cavity block with a solution of glycerol and ethanol in water. The mixture was then allowed to evaporate for $24 \mathrm{~h}$ on a warm hotplate, leaving the meiofauna in pure glycerol. Each sample was then mounted onto slides, and nematodes were identified under a compound microscope. Nematodes were identified to species level using Platt \& Warwick (1983, 1988), Warwick et al. (1998) and taxonomic literature.

Numerical analyses. The majority of statistical analyses were carried out using the non-parametric multivariate methods (Clarke \& Warwick 2001) contained in PRIMER v6 (www.primer-e.com). Bray-Curtis similarities were calculated between every pair of samples based on untransformed species abundance data. ANOSIM was used to test hypotheses concerning differences between groups of samples, and relationships between samples were visualised using non-metric multidimensional scaling (MDS). Similarity percentages breakdown (SIMPER, Clarke 1993) was used to determine species contributing to differences between groups of samples. Non-parametric Mantel tests (RELATE), using Spearman's rank correlation $(\rho)$ between corresponding elements of resemblance matrices as the test statistic, were used to explore relationships between matrices of intersample distances and similarity matrices derived from nematode abundances. To examine spatial relationships in more detail, Mantel tests were used to address the hypothesis that biotic similarities between samples a particular distance apart are higher (or lower) than similarities between samples separated by other distances, by correlating biotic similarities with model matrices in which the distance of interest was coded as 1, and all other distances as 0 . As these were all 2-tailed tests (similarities may be positively or negatively correlated with distance) we consider values of $\mathrm{p}<0.025$ and $>0.975$ to be significant (Somerfield \& Gage 2000).

An exact permutation test (Clarke et al. 2006) was applied to determine whether nematode species and Echinocardium cordatum respiratory-shaft openings were overdispersed (clumped, $D>1, \mathrm{p}<0.05$ ), underdispersed (regularly spaced, $D<1, \mathrm{p}>0.95$ ), or had a Poisson distribution (randomly distributed, $D=1$, $0.05<\mathrm{p}<0.95)$.

\section{RESULTS}

A total of 152 species of free-living nematodes were identified in the samples, including many species and genera previously unrecorded from the UK (Tables 1 \& 2). Dominant species included Perepsilonema crassum, Desmodora schulzi, Neochromadora poecilosomoides, Echinotheristus teutonicus, D. pontica, Theristus denticulatus, Spirinia gerlachi and D. sanguinea. A total of 102 species were found at 0 to $5 \mathrm{~cm}, 98$ at 5 to $10 \mathrm{~cm}$ and 95 at 10 to $15 \mathrm{~cm}$. There were small (Fig. 3) but highly significant differences in numbers of species in samples (1-way ANOVA: $F_{2,42}=23.14, p<0.0001$ ) among different sediment horizons. Average abundances per sample $\left(12.6 \mathrm{~cm}^{2}, 63 \mathrm{~cm}^{3}\right)$ ranged from 400 in the surface layer, through 262 at 5 to $10 \mathrm{~cm}$, to 162 at depths of 10 to $15 \mathrm{~cm}$, but variability in abundance was highest at intermediate depths $(\sigma=101)$, lower in the surface layer $(\sigma=88)$ and lowest in the deepest layer $(\sigma=49)$. These differences in variance precluded a test for significance between the abundances at different depths, but the pattern is clear.

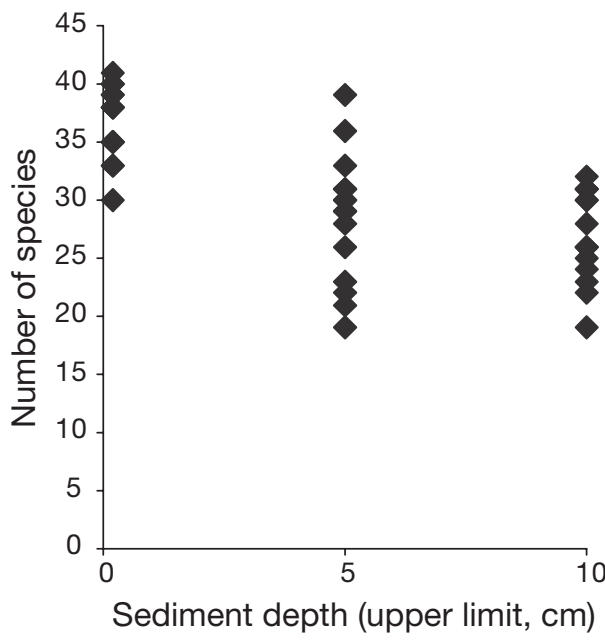

Fig. 3. Number of species in samples from 0 to 5, 5 to 10 and 10 to $15 \mathrm{~cm}$ depth 
Table 1. Total number of individuals of species with non-Poisson spatial distributions in at least 1 depth horizon $(0$ to $5 \mathrm{~cm}, 5$ to $10 \mathrm{~cm}, 10$ to $15 \mathrm{~cm}$ ) occurring in samples ( $\mathrm{N}=15$ from each depth horizon) from St Martin's flats. +: species recorded in Linnean

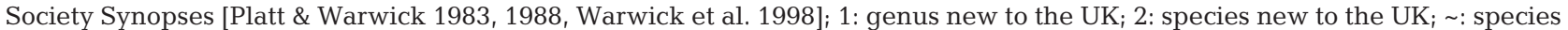
identification uncertain, probably new to the UK when generic identification known; $D$ : variance:mean ratio, values $>1$ significant $[p<0.05]$ overdispersion in an exact permutation test for departure from a Poisson distribution, 1 indicates Poisson distribution

\begin{tabular}{|c|c|c|c|c|c|c|c|c|}
\hline Species & UK status & $0-5 \mathrm{~cm}$ & $D$ & $5-10 \mathrm{~cm}$ & $D$ & $10-15 \mathrm{~cm}$ & $D$ & Total \\
\hline Perepsilonema crassum & 1,2 & 1557 & 18 & 1170 & 23 & 402 & 29 & 3129 \\
\hline Desmodora schulzi & + & 1342 & 21 & 1480 & 31 & 808 & 16 & 3630 \\
\hline Neochromadora poecilosomoides & + & 326 & 7 & 8 & 3 & & & 334 \\
\hline Echinotheristus teutonicus & 1,2 & 311 & 5 & 18 & 3 & & & 329 \\
\hline Desmodora pontica & + & 252 & 2 & 44 & 3 & 5 & 1 & 301 \\
\hline Theristus denticulatus & + & 224 & 3 & 65 & 1 & 23 & 1 & 312 \\
\hline Ixonema sordidum & 1,2 & 184 & 4 & 137 & 4 & 7 & 3 & 328 \\
\hline Prochromadorella ditlevseni & + & 175 & 4 & 4 & 2 & 10 & 1 & 189 \\
\hline Paracyatholaimus occultus & + & 155 & 6 & 96 & 3 & 16 & 2 & 267 \\
\hline Chromadorita nana & + & 143 & 5 & 45 & 2 & 5 & 2 & 193 \\
\hline Metachromadora suecica & + & 105 & 3 & 3 & 1 & 5 & 5 & 113 \\
\hline Anomonema haplostoma & 1,2 & 101 & 2 & 46 & 6 & 1 & 1 & 148 \\
\hline Calomicrolaimus parahonestus & + & 86 & 2 & 26 & 3 & 6 & 3 & 118 \\
\hline Chromadorid juvenile & $\sim$ & 71 & 3 & 2 & 2 & & & 73 \\
\hline Enoploides brunettii & + & 61 & 2 & 4 & 2 & 2 & 1 & 67 \\
\hline Manunema proboscidis & 1,2 & 58 & 3 & 70 & 4 & 2 & 1 & 130 \\
\hline Rhynchonema longituba & 2 & 55 & 6 & 118 & 2 & 85 & 4 & 258 \\
\hline Prochromadorella septempapillata & + & 51 & 2 & 0 & & 1 & 1 & 52 \\
\hline Calomicrolaimus honestus & + & 50 & 7 & 3 & 1 & 28 & 4 & 81 \\
\hline Chromadorita tentabunda & + & 47 & 5 & 6 & 1 & 2 & 1 & 55 \\
\hline Sabatieria celtica & + & 46 & 1 & 86 & 3 & 44 & 4 & 176 \\
\hline Actinonema celtica & + & 46 & 2 & 24 & 6 & 5 & 2 & 75 \\
\hline Oxystominid cf. Paroxystomina & $1, \sim$ & 44 & 1 & 34 & 1 & 10 & 3 & 88 \\
\hline Microlaimus ostracion & + & 35 & 2 & 4 & 1 & 11 & 4 & 50 \\
\hline Enoplolaimus denticulatus & + & 32 & 3 & 30 & 2 & 8 & 1 & 70 \\
\hline Hypodontolaimus sp. & $\sim$ & 27 & 6 & 2 & 2 & & & 29 \\
\hline Siphonolaimus ewensis & + & 26 & 3 & 40 & 2 & 24 & 1 & 90 \\
\hline Viscosia elegans & + & 26 & 10 & 10 & 2 & 5 & 1 & 41 \\
\hline Neochromadora trichophora & + & 25 & 3 & 2 & 1 & 1 & 1 & 28 \\
\hline Viscosia abyssorum & + & 17 & 7 & & & & & 17 \\
\hline Monoposthia mirabilis & + & 16 & 1 & 2 & 1 & 1 & 1 & 19 \\
\hline Axonolaimus orcombensis & + & 15 & 3 & 39 & 4 & 106 & 7 & 160 \\
\hline Camacolaimus longicauda & + & 13 & 1 & 23 & 1 & 16 & 1 & 52 \\
\hline Halaphanolaimus pellucidus & + & 13 & 4 & 5 & 1 & 5 & 1 & 23 \\
\hline Sigmophoranema rufum & + & 12 & 1 & 1 & 1 & 4 & 1 & 17 \\
\hline Chromaspirina multipapillata & + & 11 & 2 & 18 & 2 & 19 & 3 & 48 \\
\hline Fenestrolaimus sp. 1 & $1, \sim$ & 11 & 2 & 3 & 1 & 2 & 1 & 16 \\
\hline Cyatholaimid juvenile & $\sim$ & 10 & 4 & 1 & 1 & 3 & 1 & 14 \\
\hline Anticoma acuminata & + & 9 & 1 & 3 & 1 & & & 12 \\
\hline Paralongicyatholaimus minutus & + & 8 & 6 & 1 & 1 & 13 & 2 & 22 \\
\hline Spirinia schneideri & + & 7 & 2 & 21 & 3 & 69 & 8 & 97 \\
\hline Theristus sp. & $\sim$ & 7 & 1 & 4 & 1 & 6 & 1 & 17 \\
\hline Leptolaimus sp. & $\sim$ & 6 & 1 & 15 & 1 & 10 & 1 & 31 \\
\hline Mesacanthion africanthiforme & + & 6 & 4 & 1 & 1 & & & 7 \\
\hline Desmodorid juvenile & $\sim$ & 6 & 3 & & & 4 & 2 & 10 \\
\hline Odontophora wieseri & + & 5 & 1 & 26 & 4 & 45 & 2 & 76 \\
\hline Tarvaia angusta & + & 5 & 1 & 3 & 1 & & & 8 \\
\hline Eleutherolaimus stenosoma & + & 5 & 2 & 2 & 1 & & & 7 \\
\hline Atrochromadora microlaima & + & 5 & 5 & & & & & 5 \\
\hline Rhips paraornata & + & 5 & 3 & & & & & 5 \\
\hline Chromaspirina pellita & 2 & 4 & 1 & 18 & 1 & 75 & 3 & 97 \\
\hline Eubostrichus sp. & $1, \sim$ & 4 & 1 & 3 & 1 & 15 & 2 & 22 \\
\hline Desmodora communis & + & 4 & 1 & 3 & 1 & & & 7 \\
\hline Acanthopharynx sp. & $1, \sim$ & 4 & 1 & 2 & 1 & & & 6 \\
\hline Cyartonema elegans & + & 4 & 2 & & & 5 & 2 & 9 \\
\hline Euchromadora sp. 1 & $\sim$ & 4 & 2 & & & & & 4 \\
\hline
\end{tabular}


Table 1 (continued)

\begin{tabular}{|c|c|c|c|c|c|c|c|c|}
\hline Species & UK status & $0-5 \mathrm{~cm}$ & $D$ & $5-10 \mathrm{~cm}$ & $D$ & $10-15 \mathrm{~cm}$ & $D$ & Total \\
\hline Tricoma brevirostris & + & 3 & 1 & 7 & 1 & 4 & 1 & 14 \\
\hline Paramonhystera riemanni & + & 3 & 1 & 4 & 1 & 10 & 1 & 17 \\
\hline Theristus bastiani & + & 3 & 3 & & & 1 & 1 & 4 \\
\hline Comesa sp. & $\sim$ & 3 & 3 & & & & & 3 \\
\hline Metadesmolaimus pandus & + & 2 & 1 & 11 & 2 & 25 & 8 & 38 \\
\hline Latronema aberrans & 1,2 & 2 & 1 & 6 & 1 & 4 & 1 & 12 \\
\hline Rhabdocoma riemanni & + & 2 & 2 & 2 & 1 & 2 & 1 & 6 \\
\hline Onyx perfectus & + & 2 & 2 & 1 & 1 & 1 & 1 & 4 \\
\hline Sigmophoranema litorale & + & 2 & 2 & 1 & 1 & & & 3 \\
\hline Odontophora exharena & + & 2 & 2 & & & 10 & 3 & 12 \\
\hline Daptonema procerum & + & 2 & 1 & & & 8 & 6 & 10 \\
\hline Paracanthonchus sp. & $\sim$ & 2 & 1 & & & 4 & 1 & 6 \\
\hline Daptonema sp. & $\sim$ & 2 & 2 & & & 3 & 1 & 5 \\
\hline Spirinia laevis & + & 2 & 2 & & & & & 2 \\
\hline Stephanolaimus elegans & + & 1 & 1 & 10 & 2 & 2 & 1 & 13 \\
\hline Metalinhomoeus sp. & $\sim$ & 1 & 1 & 7 & 1 & 15 & 2 & 23 \\
\hline Amphimonhystera anechma & + & 1 & 1 & 4 & 1 & & & 5 \\
\hline Linhomoeus sp. & $\sim$ & 1 & 1 & 2 & 1 & 2 & 2 & 5 \\
\hline Spirinia gerlachi & + & & & 13 & 2 & 140 & 10 & 153 \\
\hline Desmodora sanguinea & + & & & 9 & 7 & 141 & 13 & 150 \\
\hline Paramesonchium belgicum & 1,2 & & & 8 & 1 & 30 & 2 & 38 \\
\hline Thalassomonhystera parva & + & & & 6 & 3 & & & 6 \\
\hline Paralinhomeous uniovarium & + & & & 4 & 2 & 1 & 1 & 5 \\
\hline Metadesmolaimus gelana & + & & & 4 & 1 & & & 4 \\
\hline Leptonemella aphanothecae & + & & & 3 & 1 & 15 & 2 & 18 \\
\hline Astomonema sp. & $\sim$ & & & 3 & 1 & 5 & 2 & 8 \\
\hline Praeacanthonchus inglisi & + & & & 3 & 3 & & & 3 \\
\hline Siphonolaimus cobbi & + & & & 2 & 2 & & & 2 \\
\hline Metadesmolaimus sp. 3 & $\sim$ & & & 1 & 1 & 10 & 3 & 11 \\
\hline Microlaimus acinaceus & + & & & 1 & 1 & 6 & 2 & 7 \\
\hline Chromaspirina sp. & $\sim$ & & & & & 15 & 2 & 15 \\
\hline Paralinhomoeus tenuicaudatus & + & & & & & 6 & 3 & 6 \\
\hline Daptonema sp. 1 & $\sim$ & & & & & 5 & 3 & 5 \\
\hline Stephanolaimus bicornatus & 2 & & & & & 3 & 3 & 3 \\
\hline Nannolaimus fusus & + & & & & & 2 & 2 & 2 \\
\hline
\end{tabular}

There was a clear gradient in community structure from the sediment surface to deeper sediment horizons (Tables 1 \& 2, Fig. 4), reflected in a 2-way ANOSIM test for differences in assemblages collected from different depths averaged across different corners of the triangular design $(R=0.697, \mathrm{p}<0.001)$. Analysis by SIMPER showed, as might be expected, that approximately $50 \%$ of the Bray-Curtis dissimilarity between sediment horizons was contributed by decreases in abundances of dominant species (Perepsilonema crassum, Neochromadora poecilosomoides, Echinotheristus teutonicus, Theristus denticulatus, Pseudochromadora pontica and Desmodora schulzi) with increasing depth. Species with relatively more importance in the deeper sediments included D. sanguinea and Spirinia gerlachi (Table 1).

No nematode species were significantly underdispersed (Tables 1 \& 2), but many species were overdispersed (Table 1) in 1 or more depth horizons, and in each horizon there was a significant relation- ship between the variance:mean ratio $(D)$ of species and their abundances (Fig. 5). A total of $50 \%$ of species were overdispersed in the 0 to $5 \mathrm{~cm}$ horizon; $35 \%$ at 5 to $10 \mathrm{~cm}$; and $41 \%$ at 10 to $15 \mathrm{~cm}$. The similarity in

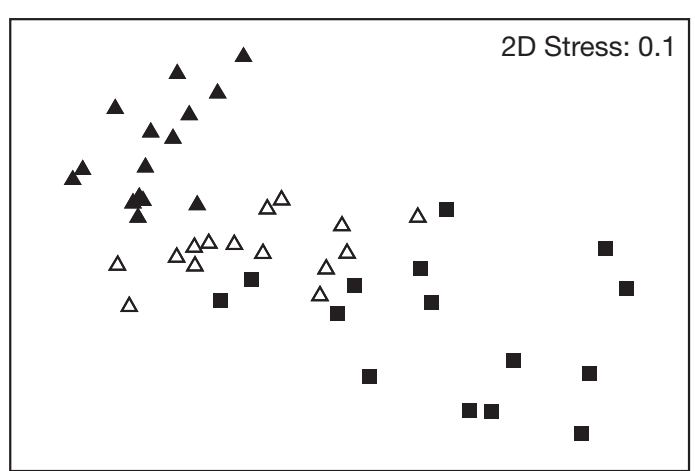

Fig. 4. MDS ordination of samples based on Bray-Curtis similarities computed from abundances of free-living nematodes

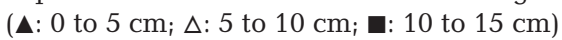


Table 2. Total number of individuals of species for which an exact permutation test showed no evidence for departure from Poisson distribution in any depth horizon ( 0 to $5 \mathrm{~cm}, 5$ to $10 \mathrm{~cm}, 10$ to $15 \mathrm{~cm}$ ) occurring in samples ( $\mathrm{N}=15$ from each depth horizon) from St Martin's flats. +: species recorded in Linnean Society Synopses [Platt \& Warwick 1983, 1988, Warwick et al. 1998]; 1: genus new to the $\mathrm{UK}_{;} 2$ : species new to the $\mathrm{UK}_{;} \sim$ : species identification uncertain, probably new to the UK when generic identification known

\begin{tabular}{|c|c|c|c|c|c|}
\hline Species & $\begin{array}{l}\text { UK } \\
\text { status }\end{array}$ & $\begin{array}{l}0-5 \\
\mathrm{~cm}\end{array}$ & $\begin{array}{c}5-10 \\
\mathrm{~cm}\end{array}$ & $\begin{array}{c}10-15 \\
\mathrm{~cm}\end{array}$ & Total \\
\hline Gammanema rapax & + & 3 & 2 & 3 & 8 \\
\hline Halalaimus sp. & $\sim$ & 3 & 1 & & 4 \\
\hline Paramonhystera sp. & $\sim$ & 3 & 1 & & 4 \\
\hline Leptonemella granulosa & 2 & 3 & & 3 & 6 \\
\hline Viscosia viscosa & + & 2 & 1 & & 3 \\
\hline Paracanthonchus longus & + & 2 & & 2 & 4 \\
\hline Araeolaimus sp. & $\sim$ & 2 & & & 2 \\
\hline Chromadora nudicapitata & + & 2 & & & 2 \\
\hline Chromaspirina parapontica & $\sim$ & 2 & & & 2 \\
\hline Metachromadora scotlandica & + & 2 & & & 2 \\
\hline Microlaimus conothelis & + & 2 & & & 2 \\
\hline Pontonema vulgare & + & 2 & & & 2 \\
\hline Rhabdocoma wrong tail & $\sim$ & 2 & & & 2 \\
\hline Paradesmodora sp. & $1, \sim$ & 1 & & 2 & 3 \\
\hline Paralinhomoeus sp. 1 & $\sim$ & 1 & & 2 & 3 \\
\hline Enoplolaimus propinquus & + & 1 & & 1 & 2 \\
\hline Axonolaimus spinosus & + & 1 & & & 1 \\
\hline Belbolla sp. & $\sim$ & 1 & & & 1 \\
\hline Desmodora tenuispiculum & + & 1 & & & 1 \\
\hline Enoploides spiculohamatus & + & 1 & & & 1 \\
\hline Eurystomina sp. & $\sim$ & 1 & & & 1 \\
\hline Fenestrolaimus sp. & $1, \sim$ & 1 & & & 1 \\
\hline Linhomoeus sp. 1 & $\sim$ & 1 & & & 1 \\
\hline Metadasynemoides sp. & $1, \sim$ & 1 & & & 1 \\
\hline Stylotheristus sp. & $1, \sim$ & 1 & & & 1 \\
\hline Terschellingia longicaudata & + & 1 & & & 1 \\
\hline Theristus sp. & $\sim$ & 1 & & & 1 \\
\hline Tricoma longirostris & + & & 3 & 1 & 4 \\
\hline Filitonchus ewensis & + & & 2 & 2 & 4 \\
\hline Odontophora villoti & + & & 2 & 2 & 4 \\
\hline Spirinia parasitifera & + & & 2 & & 2 \\
\hline Ascolaimus elongatus & + & & 1 & 1 & 2 \\
\hline Daptonema invagiforoum & + & & 1 & 1 & 2 \\
\hline Xyala sp. & $\sim$ & & 1 & 1 & 2 \\
\hline Chromadorella sp. & $\sim$ & & 1 & & 1 \\
\hline Cyartonema germanicum & + & & 1 & & 1 \\
\hline Dasynemoides sp. & $\sim$ & & 1 & & 1 \\
\hline Enoplus quadridentatus & + & & 1 & & 1 \\
\hline Gerlachius novusetosus & + & & 1 & & 1 \\
\hline Mesacanthion hirsutum & + & & 1 & & 1 \\
\hline Metoncholaimus scanicus & + & & 1 & & 1 \\
\hline Neotochus sp. & $\sim$ & & 1 & & 1 \\
\hline Paracyatholaimoides multispiralis & + & & 1 & & 1 \\
\hline Pontonema reducta & + & & 1 & & 1 \\
\hline Syringolaimus sp. & $1, \sim$ & & 1 & & 1 \\
\hline Theristus sp. 1 & $\sim$ & & 1 & & 1 \\
\hline Trileptium sp. & $\sim$ & & 1 & & 1 \\
\hline Axonolaimus hexapilus & + & & & 3 & 3 \\
\hline Neochromadora sp. & $\sim$ & & & 2 & 2 \\
\hline Calomicrolaimus acanthus & + & & & 1 & 1 \\
\hline Enoplolaimus litoralis & + & & & 1 & 1 \\
\hline Choniolaimus sp. & $\sim$ & & & 1 & 1 \\
\hline Halichoanolaimus/Latronema & $\sim$ & & & 1 & 1 \\
\hline Paracanthonchus longicaudatus & + & & & 1 & 1 \\
\hline Paralinhomeous lepturus & + & & & 1 & 1 \\
\hline Pselionema sp. & $\sim$ & & & 1 & 1 \\
\hline Pterygonema sp. & $\sim$ & & & 1 & 1 \\
\hline Richtersia inequalis & + & & & 1 & 1 \\
\hline Stephanolaimus sp. 1 & $\sim$ & & & 1 & 1 \\
\hline Thalassironus sp. & $\sim$ & & & 1 & 1 \\
\hline
\end{tabular}

$D$-values for individual species (Tables 1 \& 2 ), and in the relationships between $D$ and abundance (Fig. 5), at different depths indicate that a species' tendency to aggregate is relatively constant and not markedly influenced by the depth at which it occurs.

The results of Mantel tests of the overall relationships between intersample similarities and distances between sample locations in different depth horizons (Table 3) clearly show that there was a significant relationship between distance and similarity among samples taken from the 5 to $10 \mathrm{~cm}$ horizon, with samples collected closer together tending to be more similar. The relationship was weaker (and failed to achieve significance at the $\mathrm{p}=0.025$ level) in the 10 to $15 \mathrm{~cm}$ horizon and was practically non-existent $(R<0.1)$ in the surface (0 to $5 \mathrm{~cm}$ ) layers.

There was a significant positive shortorder spatial autocorrelation in surface $(0$ to $5 \mathrm{~cm}$ ) samples, meaning that samples collected $10 \mathrm{~cm}$ apart were significantly more alike than samples collected further apart (Table 3). Spatial relationships were stronger in the 5 to $10 \mathrm{~cm}$ horizon. As well as significant positive autocorrelation among samples $10 \mathrm{~cm}$ apart, there was also significant negative autocorrelation among samples $10 \mathrm{~m}$ apart (samples were significantly less similar than samples collected closer together). Tests for spatial relationships among samples from the 10 to $15 \mathrm{~cm}$ horizon failed to achieve significance at the $0.025>$ p > 0.975 level. Looking at broad patterns, rather than only 'significant' results, it can be seen that there is a switch from a positive relationship between similarity and distance over short distances in the surface layers to a negative relationship when samples are approximately $1 \mathrm{~m}$ apart, and there is almost no relationship $(R<0.1)$ among samples taken $10 \mathrm{~m}$ from each other. At intermediate depths (5 to $10 \mathrm{~cm}$ ) a strong positive relationship between similarity and distance switches to a negative relationship when samples are somewhere between 1 and $10 \mathrm{~m}$ apart, while deeper still there is almost no relationship $(R<0.1)$ among samples taken $10 \mathrm{~cm}$ from each other, but a weak positive relationship between similarity and distance for samples collected $1 \mathrm{~m}$ apart 

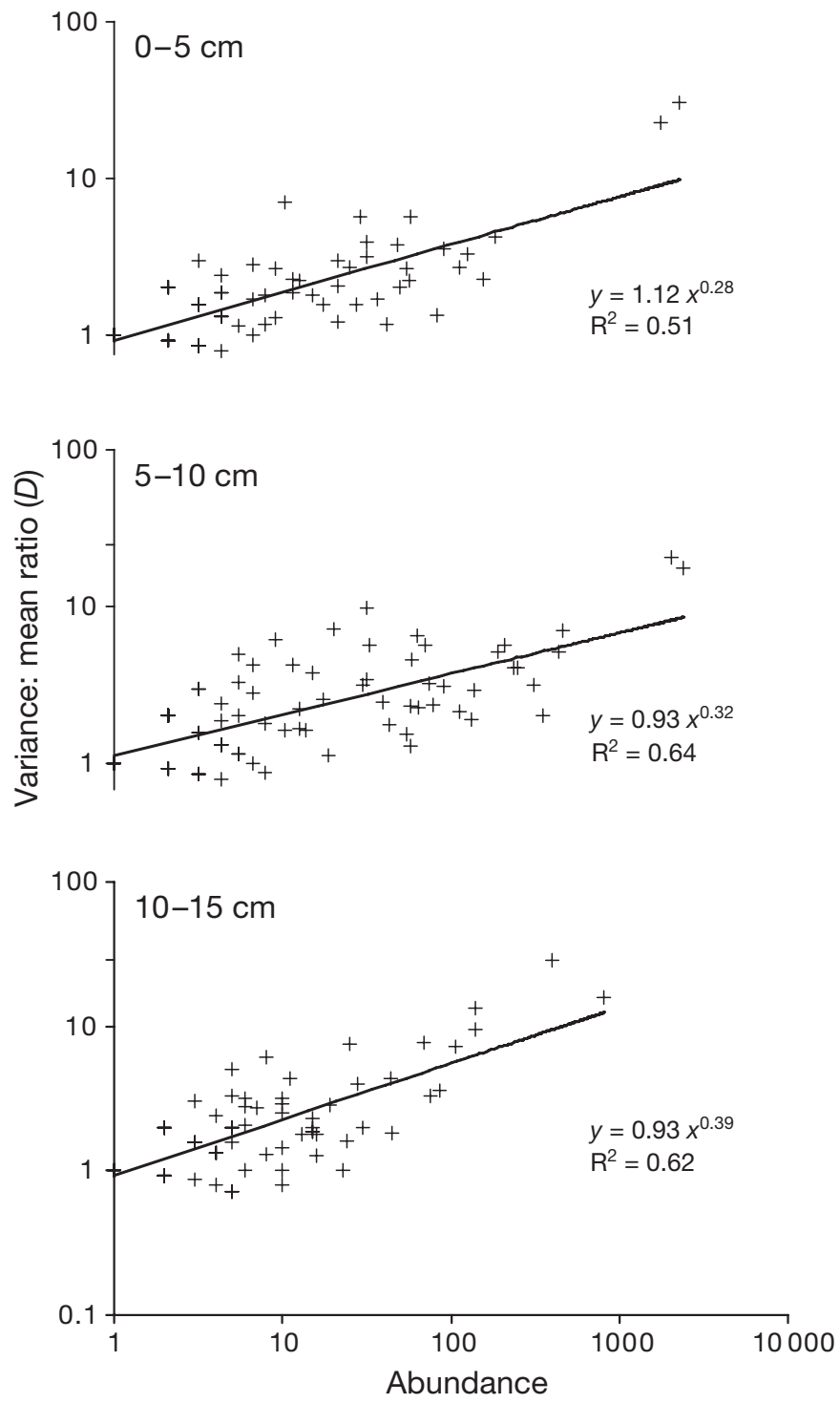

Fig. 5. Relationship between variance:mean ratio $(D)$ and abundance for nematode species in each depth horizon

Table 3. Results of non-parametric Mantel tests of 'no relationship' between Bray-Curtis similarity matrices derived from untransformed nematode abundances in different depth horizons and matrices representing distances between sampling locations ('all distances'), and model matrices to test whether similarities between samples a certain distance apart are greater (or less) than samples separated by other distances ( $\rho$ : Spearman's rank correlation coefficient between corresponding elements of the 2 matrices; p: significance level estimated from 5000 permutations; bold print indicates $\mathrm{p}<0.025$ or $>0.0975$ )

\begin{tabular}{|c|c|c|c|c|c|c|}
\hline & \multicolumn{2}{|c|}{$0-5 \mathrm{~cm}$} & \multicolumn{2}{|c|}{$5-10 \mathrm{~cm}$} & \multicolumn{2}{|c|}{$10-15 \mathrm{~cm}$} \\
\hline & $\rho$ & $\mathrm{p}$ & $\rho$ & $\mathrm{p}$ & $\rho$ & $\mathrm{p}$ \\
\hline All distances & 0.079 & 0.128 & 0.287 & 0.005 & 0.189 & 0.041 \\
\hline $0.1 \mathrm{~m}$ vs. remainder & 0.282 & 0.003 & 0.259 & 0.009 & 0.076 & 0.205 \\
\hline $1.0 \mathrm{~m}$ vs. remainder & -0.160 & 0.968 & 0.120 & 0.081 & 0.167 & 0.057 \\
\hline 10 m vs. remainder & -0.033 & 0.699 & -0.267 & 0.990 & -0.195 & 0.969 \\
\hline
\end{tabular}

switching to a negative one for samples collected $10 \mathrm{~m}$ from each other.

Most Echinocardium cordatum were located 10 to $15 \mathrm{~cm}$ below the sediment surface, at a density between $1.36 \mathrm{~m}^{-2}$ (the density of respiratory-shaft openings) and an estimated maximum of $10 \mathrm{~m}^{-2}$ observed in carefully dug pits. The respiratory shafts were significantly underdispersed (variance:mean ratio $D=0.71$, $\mathrm{p}=0.988$ ), implying that the animals were spacing themselves maximally within the sediment.

\section{DISCUSSION}

Warwick et al. (2006) found 207 species of nematodes in a collection of samples totalling nearly $112 \mathrm{l}$ in volume, but sieved on a range of mesh sizes, collected from a nearby site on St Martin's flats. The 152 species of nematodes reported here were extracted from only 2.81 of sand. Warwick et al. (2006) reported that spatial separation of samples had little or no effect on clustering patterns of the total fauna, and that among species the meiofaunal size range $<30 \%$ showed significant -Poisson) spatial clustering. They collected cores $20 \mathrm{~cm}$, and concluded that the vertical component of spatial distribution could be driving observed differences in clustering among smaller-sized organwith significantly overdispersed distributions in $5 \mathrm{~cm}$ sections of core ranged from 35 to $50 \%$. Interestingly, the strongest overdispersion and highest abundances occurred in the surface layers ( 0 to $5 \mathrm{~cm}$ ), but the strongest overall spatial pattern, based on analyses of untransformed abundances of all species, was found in the intermediate ( 5 to $10 \mathrm{~cm}$ ) horizon, where the proportion of individual species with overdispersed distributions was lowest (35\%). This reinforces the statement made in the introduction that whether spatial pattern is observed or not depends critically on how it is defined.

Although a few studies have examined synchronous vertical and horizontal spatial patterns of nematodes (e.g. Platt 1977, Steyaert et al. 2003), the horizontal component of these studies has been confounded by the choice of sites known to differ in terms of their position on the shore, granulometry and sediment environmental conditions. We believe that ours is the first study to examine horizontal and vertical distributions synchronously within a homogeneous intertidal sediment. Fleeger \& Decho (1987) outline some of the difficulties involved in 
separating out various factors potentially affecting meiofaunal spatial distributions within sands, especially the fact that many of them are inter-related. Spatial patterns may appear as a result of aggregation or dispersion of organisms, or as a result of in situ reproduction, in the absence of environmental heterogeneity. Such patterns may be broken down by physical and biological processes. Conversely, responses by organisms to variation in such processes may create spatial patterns, and this has been the focus of most explanations of observed spatial patterns of meiofauna. Spatial patterns do not always reflect processes that are occurring concurrently with sample collection (Hogue \& Miller 1981), and caution must be exercised when attempts are made to explain spatial distributions of animals from physical or biological conditions measured at a single point in time. We believe, however, that our findings that horizontal spatial patterns in the surface $5 \mathrm{~cm}$ of sediment are significant over short distances, are strongest in the intermediate 5 to $10 \mathrm{~cm}$, and are weak and generally insignificant at 10 to $15 \mathrm{~cm}$ give clues to the processes that may be important in their generation and maintenance.

Processes considered to be capable of generating small-scale spatial aggregation among meiofauna include attraction to patchily distributed food (e.g. Hogue \& Miller 1981), association with biogenic sediment structures (Ólafsson 2003), small-scale variation in sediment composition (Nichols 1980), biotic interactions with macrofauna (Ólafsson 2003) and with other meiofauna (Moens et al. 2000), and differences in species' ecophysiology (Wieser \& Scheimer 1977). Platt (1977) concluded that horizontal distributions largely result from responses of species to specific combinations of the degree of environmental stability, the nature of the available food and the particle size composition of the sediment. Hogue \& Miller (1981) found increased abundances of nematodes beneath the crests of sand ripples in the surface layers of an intertidal sand, and proposed a mechanism whereby the observed aggregation of nematodes was a consequence of their attraction to a food resource that was itself spatially structured by physical processes. In a study of spatial distributions of nematodes in relation to wave-generated sediment disturbance in sands at 18 to $32 \mathrm{~m}$ on an exposed coast, Hogue (1982) concluded that aggregation of nematodes was reduced by sediment mixing by storm activity in the winter, whereas a reduction in physical disruption allowed biological factors (food and reproduction) to lead to aggregation in summer. Recent work (e.g. de Beer et al. 2005, Røy et al. 2005) has highlighted the importance of the interplay between water-column hydrodynamics, interstitial water flows and biogeochemical processes in permeable sediments. Variations in surface topography, be they of biogenic (mounds, pits) or hydrodynamic (ripples, sandwaves) origin, induce spatial heterogeneity at and beneath the sediment surface through the induction of alternating pressure gradients, which drive water into, and draw water out of, interstitial spaces in the sediment. This interfacial advection carries particles, oxygen and nutrients into the sediment, where they encounter microbial communities on the surfaces of sediment particles. Such physico-biological processes must be important determinants of meiofaunal distributions. Processes resulting from interfacial advection almost certainly played a role in producing the patterns observed by Hogue \& Miller (1981) and Hogue (1982), and we believe that they probably play a major role in influencing both horizontal and vertical differences in nematode community structure among the sediment horizons observed in this study. Such small-scale effects of hydrodynamics on spatial structure are likely to be dynamic and short-lived, changing with every tidal cycle, or possibly in some cases with the passage of individual waves.

In the upper $1 \mathrm{~cm}$ of a sandy estuarine tidal flat Blome et al. (1999) found a difference in aggregation patterns between 'diatom feeders' (a diverse assemblage containing epistrate and non-selective deposit feeders, sensu Wieser 1953) and relatively long and slender nematodes with thin smooth cuticles, which may be capable of transepidermal uptake of dissolved organic matter (Jensen 1987), termed DOM-users. A similar division in morphotypes has been interpreted as evidence of adaptation to physical stress (Ward 1975, Hogue 1982), as shallow, wave-disturbed sediments tended to be inhabited by short $(<1100 \mu \mathrm{m})$ species with annulations, spines, or other ornamentation. In the present study, some of the species that decreased in abundance with increasing depth are small and possess long setae or spines (Perepsilonema crassum, Echinotheristus teutonicus, Theristus denticulatus), while others have heavily annulated cuticles (Neochromadora poecilosomoides, Pseudochromadora pontica, Desmodora schulzi). Species with more importance in the deeper sediments (Desmodora sanguinea and Spirinia gerlachi) are relatively long with very sluggish movement and presumably low metabolic requirements, and are more typical of the DOM-user group. Naturally there is a relationship between hydrodynamic forces and sediment structure, so the extent to which the relationship between sediment structure and the community structure of the nematodes within those sediments is determined by the same forces, or reflects physiological or ecological responses to environmental conditions within the sediments, is still an open question.

Echinocardium cordatum were underdispersed, perhaps to reduce competition and maximise the use of 
spatially distributed resources. Densities (1.36 to $10 \mathrm{~m}^{-2}$ ) and depth distribution (10 to $15 \mathrm{~cm}$ ) are entirely consistent with observations of intertidal UK populations made previously (Buchanan 1966). Animals move through the sediment at 6 to $8 \mathrm{~cm} \mathrm{~h}^{-1}$ (Buchanan 1966) and are typically $3 \mathrm{~cm}$ in length (Buchanan 1966), with a corresponding cross-sectional area of 6 to $7 \mathrm{~cm}^{2}$ (Lohrer et al. 2005), although the functional cross-sectional area is probably greater, owing to the action of tube-feet and spines (Nichols 1959, Buchanan 1966). Thus, at a density of $10 \mathrm{~m}^{2}$, a population can rework $>10 \mathrm{l} \mathrm{d}^{-1}$ of sand, or all the sand in a $5 \mathrm{~cm}$ deep horizon at least once every $5 \mathrm{~d}$. Lohrer et al. (2005) calculate that a subtidal New Zealand Echinocardium population is also capable of reworking a $5 \mathrm{~cm}$ thick layer of sediment every 3 to $5 \mathrm{~d}$, although subtidal populations tend to be denser, but slower moving (Buchanan 1966). The absence of strong spatial structure in the nematode assemblages in this sediment horizon could, therefore, be a result of environmental homogenisation by this population of bioturbators. The majority of studies examining relationships between bioturbators and meiofaunal community structure (see Ólafsson 2003) have focused on the role of bioturbators in increasing environmental heterogeneity, leading to statements that bioturbators are 'critical' to the maintenance of infaunal diversity (Widdicombe \& Austen 1998). While there is no doubt that some larger organisms modify the environment to produce microhabitats that support particular populations of meiofaunal organisms, our results remind us that larger organisms may also act to break down environmental heterogeneity and therefore, presumably, to reduce infaunal diversity.

Echinocardium cordatum is considered to be a nonselective deposit feeder. It is entirely possible that these animals contribute to nematode spatial patterns by digestion of nematodes in the sediment and by competition for food which could, in part, explain the decrease in nematode abundance with depth in the sediment. However, the volume of sediment reworked by a related echinoid, Brissopsis lyrifera, while burrowing exceeded the volume ingested by 60 to 150 times (Hollertz \& Duchêne 2001), and we believe, therefore, that the primary interaction between the urchins and the nematodes results from the reworking activities of the former.

In conclusion, different processes operate to generate or remove spatial patchiness in each depth horizon. In the surface layers, physical disturbance homogenises the nematode assemblage at larger spatial scales, while short-term, smaller-scale features such as ripples and buried algal debris introduce small-scale patchiness, at least in part as a result of advective processes. A dense population of Echinocardium corda- tum inhabits the sand, concentrated between 10 and $15 \mathrm{~cm}$ deep, and the activities of these bioturbators are likely to homogenise the sediment at this depth, removing patchiness. The strongest spatial pattern was found at intermediate depths (5 to $10 \mathrm{~cm}$ ). Between the dynamic surface layer, which is likely to be disturbed and to some extent redistributed each tidal cycle, and a deeper layer, which is likely to be disturbed daily by burrowing urchins, is an intermediate region where environmental heterogeneity, when created, may last long enough for spatial patterns to become established. Our study highlights the potential importance of the interaction between sediment permeability, and therefore interfacial advection, and bioturbation in controlling infaunal diversity and spatial patterns.

Acknowledgements. This study was supported by the UK Department for Environment, Food and Rural Affairs (DEFRA) under Contract Nos. AE 1137, CDEP 84/5/295 and ME3109, and is a contribution to P.M.L.'s core strategic research programme. We thank all those who assisted with this study, particularly A. E. Somerfield for discussions about random walks, and J. Harris and M. Austen for help with the sampling.

\section{LITERATURE CITED}

Blome D, Schleier U, Bernem KH v (1999) Analysis of the small-scale spatial patterns of free-living marine nematodes from tidal flats in the east Frisian Wadden Sea. Mar Biol 133:717-726

Buchanan JB (1966) The biology of Echinocardium cordatum [Echinodermata: Spatangoidea] from different habitats. J Mar Biol Assoc UK 46:97-114

Clarke KR (1993) Non-parametric multivariate analyses of changes in community structure. Aust J Ecol 18:117-143

Clarke KR, Warwick RM (2001) Change in marine communities: an approach to statistical analysis and interpretation, 2nd edn. PRIMER-E, Plymouth

Clarke KR, Chapman MG, Somerfield PJ, Needham HR (2006) Dispersion-based weighting of species counts in assemblage analyses. Mar Ecol Prog Ser 320:11-27

de Beer D, Wenzhöfer F, Ferdelman TG, Boehme SE and 5 others (2005) Transport and mineralization rates in North Sea sandy intertidal sediments, Sylt-Rømø Basin, Wadden Sea. Limnol Oceanogr 50:113-127

Fleeger JW, Decho AW (1987) Spatial variability of interstitial meiofauna: a review. Stygobiologia 3:35-54

Hogue EW (1982) Sediment disturbance and the spatial distributions of shallow water meiobenthic nematodes on the open Oregon coast. J Mar Res 40:551-573

Hogue EW, Miller CB (1981) Effects of sediment microtopography on small-scale spatial distributions of meiobenthic nematodes. J Exp Mar Biol Ecol 53:181-191

Hollertz K, Duchêne JC (2001) Burrowing behaviour and sediment reworking in the heart urchin Brissopsis lyrifera Forbes (Spatangoida). Mar Biol 139:951-957

Jensen P (1987) Feeding ecology of free-living aquatic nematodes. Mar Ecol Prog Ser 35:187-196

Joint IR, Gee JM, Warwick RM (1982) Determination of finescale vertical distribution of microbes and meiofauna in an intertidal sediment. Mar Biol 72:157-164 
Lohrer AM, Thrush SF, Hunt L, Hancock N, Lundquist C (2005) Rapid reworking of subtidal sediments by burrowing spatangoid urchins. J Exp Mar Biol Ecol 321:155-169

Moens T, Herman PMJ, Verbeeck L, Steyaert M, Vincx M (2000) Predation rates and prey selectivity of two predacious marine nematode species. Mar Ecol Prog Ser 205:185-193

Nichols D (1959) Changes in the chalk heart-urchin Micraster interpreted in relation to living forms. Phil Trans R Soc B 242:347-437

Nichols JA (1980) Spatial pattern of a free-living marine nematode community off the coast of Peru. Int Rev Gesamten Hydrobiol 65:249-257

Ólafsson E (2003) Do macrofauna structure meiofauna assemblages in marine soft bottoms? Vie Milieu 53:249-265

Platt HM (1977) Vertical and horizontal distribution of freeliving marine nematodes from Strangford Lough, Northern Ireland. Cah Biol Mar 28:261-273

Platt HM, Warwick RM (1983) Freeliving marine nematodes. Part I: British enoplids. Synopses of the British fauna (new series), No. 28, Cambridge University Press, Cambridge

Platt HM, Warwick RM (1988) Freeliving marine nematodes. Part II: British chromadorids. Synopses of the British fauna (new series), No. 38, E. J. Brill/W. Backhuys, Leiden

Røy H, Huettel M, Jørgensen BB (2005) The influence of topography on the functional exchange surface of marine soft sediments, assessed from sediment topography measured in situ. Limnol Oceanogr 50:106-112

Somerfield PJ, Gage JD (2000) Community structure of the benthos in Scottish Sea-lochs. IV. Multivariate spatial pattern. Mar Biol 136:1133-1145

Somerfield PJ, Warwick RM (1996) Meiofauna in marine pollution monitoring programmes: a laboratory manual. MAFF Directorate of Fisheries Research Technical Series, Lowestoft

Editorial responsibility: Lisa Levin (Contributing Editor), La Jolla, California, USA
Somerfield PJ, Warwick RM, Moens T (2005) Chapter 6: Meiofauna techniques. In: Eleftheriou A, McIntyre A (eds) Methods for the study of marine benthos, 3rd edn. Blackwell Science, Oxford, p 229-272

Steyaert M, Herman PMJ, Moens T, Widdows J, Vincx M (2001) Tidal migration of nematodes on an estuarine tidal flat (the Molenplaat, Schelde Estuary, SW Netherlands). Mar Ecol Prog Ser 224:299-304

Steyaert M, Vananerbeke J, Vanreusel A, Barranguet C, Lucas C, Vincx M (2003) The importance of fine-scale, vertical profiles in characterising nematode community structure. Estuar Coast Shelf Sci 58:353-366

Ward AR (1975) Studies on the sublittoral free-living nematodes of Liverpool Bay. II. Influence of sediment composition on the distribution of marine nematodes. Mar Biol 30: $217-225$

Warwick RM, Platt HM, Somerfield PJ (1998) Freeliving marine nematodes. Part III: monhysterids. Synopses of the British fauna (new series), No. 53. Field Studies Council, Shrewsbury

Warwick RM, Dashfield SL, Somerfield PJ (2006) The integral structure of a benthic infaunal assemblage. J Exp Mar Biol Ecol 330:12-18

Widdicombe S, Austen MC (1998) Experimental evidence for the role of Brissopsis lyrifera (Forbes, 1841) as a critical species in the maintenance of benthic diversity and the modification of sediment chemistry. J Exp Mar Biol Ecol 228:241-255

Wieser W (1953) Die Beziehung zwischen Mundhöhlengestalt, Ernährungsweise und Vorkommen bei freilebenden marinen Nematoden. Ark Zool 2:439-484

Wieser W, Scheimer F (1977) The ecophysiology of some marine nematodes from Bermuda: seasonal aspects. J Exp Mar Biol Ecol 26:97-106

Submitted: January 12, 2006; Accepted: September 19, 2006 Proofs received from author(s): April 10, 2007 